\title{
Assessment of Irrigation Potential in Jewuha Watershed, Middle Awash River Basin, Ethiopia
}

Manamno Beza Dinku ( $\triangle$ manamnobeza@yahoo.com )

Wolaita Sodo University https://orcid.org/0000-0002-3698-7471

Habtamu Hailu Kebede

Addis Ababa Science and Technology University

Research Article

Keywords: Land suitability, SWAT, GIS, CROPWAT, Irrigation potential

Posted Date: February 15th, 2022

DOI: https://doi.org/10.21203/rs.3.rs-1202254/v1

License: (9) This work is licensed under a Creative Commons Attribution 4.0 International License.

Read Full License 


\title{
Assessment of Irrigation Potential in Jewuha Watershed, Middle Awash River Basin, Ethiopia
}

\author{
Manamno Beza ${ }^{*}$ and Habtamu Hailue ${ }^{2}$ \\ ${ }^{[1]}$ Department of Hydraulic and Water resource engineering, College of Engineering and Technology, Wolaita \\ Sodo University, Wolaita Sodo, Ethiopia \\ ${ }^{[2]}$ Assistant Professor of Water Resources Engineering at the Department of Civil Engineering, College of \\ Architecture and Civil Engineering, Addis Ababa Science and Technology University, Addis Ababa, Ethiopia \\ *Corresponding Author: manamnobeza@yahoo.com
}

Co-author:habt72@yahoo.com

\section{ABSTRACT}

Ethiopia is endowed with immense water and land resources that could be tapped and used for irrigation development. However, little has been done so far due mainly to lack of comprehensive knowledge on the potential of these resources. This study was, therefore, taken up to assess the irrigation potential in data scarce Jewuha watershed of the Awash River Basin. To achieve the objective of the study, the suitability of the land for both surface and pressurized irrigations was estimated using a parametric evaluation technique combined with the FAO land evaluation framework in the GIS environment with multi-criteria analysis of irrigation suitability factors. The irrigation water demands of major crops adopted in the area were determined using CROPWAT software. The surface water potential at the sub watershed was estimated using a combination of SWAT model and the spatial proximity regionalization technique. The performance of the SWAT model was checked by statistical parameters.

11 The irrigation suitability analysis reveals that 51372ha of the study area are suitable and 16274ha are unsuitable for 12 surface irrigation system. Furthermore, 52768ha of the area are suitable and 15088ha are unsuitable for a sprinkler 13 irrigation system. For drip irrigation, 52751ha are suitable and 14855ha are unsuitable. The calibration and 14 validation of SWAT model showed that the model has performed well to simulate the hydrology of the watershed 15 with a coefficient of determination $\left(\mathrm{R}^{2}\right.$ ), Nash-Sutcliffe efficiency (NSE) and Percent of bias (PBIAS) of $0.74,0.73$ 16 and 0.80 for calibration and $0.71,0.70$ and 7.90 for validation, respectively. From a combined analysis of the 17 available land and water resources, the gross irrigation potential of the area is estimated to be 12,997ha, of which 3098ha of land is exclusively suitable for surface irrigation and 9,899ha is suitable for pressurized irrigation 19 systems.

20 Key words: Land suitability, SWAT, GIS, CROPWAT, Irrigation potential

\section{$21 \quad 1 \quad$ Introduction}

22 Over 85 percent of Ethiopia's population lives in rural areas and relies on agriculture for subsistence (Awulachew et 23 al. 2007). The country has huge water resource potential that comprises 12 river basins with an annual runoff 24 volume of 124 billion $\mathrm{m}^{3}$ of water and over 2.6 billion $\mathrm{m}^{3}$ of groundwater potential (Melesse et al. 2014; Worku 25 Ayalew 2018). But there is not sufficient water for most farmers to produce more than one crop per year due to a 
lack of water storage structures and large spatial and temporal variations in rainfall. Therefore, irrigation

27 development and improved agricultural water management practices could provide opportunities to cope with the

28 impact of climatic variability, enhance productivity per unit of land, and increase the annual crop production volume

29 significantly(Awulachew and Merrey 2005).

30 Ethiopia also has a total cultivable land of between 30 to 70 million hectares out of 112 million hectares, but only 15

31 million hectares of land is under cultivation. However, only about $4 \%$ of this cultivated area has been irrigated so far

32 (Awlachew et al. 2010), despite the fact that there is no precise figure for the potential and actual irrigated area. This

33 is due to a lack of consistent, reliable inventory, well-studied and documented data. Also, this shows that there is a

34 lack of detailed studies in the area. So, assessment of irrigation potential for irrigation development is important to

35 utilize the land resources efficiently for the sustainable production of crops and to sustain the food security of the

36 rapidly increasing population in the country (Haile 2015). Among the 12 river basins in Ethiopia, the Awash river

37 basin is one of them, covering a total area of $110,000 \mathrm{~km}^{2}$. The Awash river basin is the most intensively utilized

38 river basin for irrigation development in Ethiopia due to its strategic location, accessibility, available land, and water

39 resources (Awash Basin Authority 2017). However, the most utilized part is the upper part of the basin and relative

40 to the total area, there is very little area to be utilized. Due to this, assessing irrigation potential in the Awash River

41 basin is needed for more effective use of the basin for agricultural development.

42 Irrigation development could improve agricultural productivity and enhance socio-economic development through 43 the growth of production (AU 2020). But most of Ethiopia, particularly in the study area, practiced traditional 44 agricultural activity. This shows that irrigation development in the study area is necessary and to do this, first the 45 potential site for irrigation must be identified. Therefore, the objective of this study is to assess the irrigation 46 potential for different irrigation systems in the Jewuha watershed to easily develop an irrigation project and the 47 surface water resource potential is assessed using the SWAT model (Arnold et al. 2012). Furthermore, the irrigation 48 water demand of the major crops adopted in the study area was estimated using the CROPWAT model (FAO 1992).

\section{Materials and Methods}

\section{$50 \quad 2.1 \quad$ Description of the study area}

51 Jewuha watershed is located in the Awash river basin. It is geographically located between $39^{\circ} 44^{\prime} 55^{\prime \prime}$ to $40^{\circ} 10^{\prime} 44^{\prime} \mathrm{E}$ 52 and $10^{\circ} 00^{\prime} 3 "$ to $10^{\circ} 21^{\prime} 10^{\prime \prime} \mathrm{N}$. The watershed is $240 \mathrm{~km}$ away from the capital city Addis Ababa in the northeast 53 direction. 


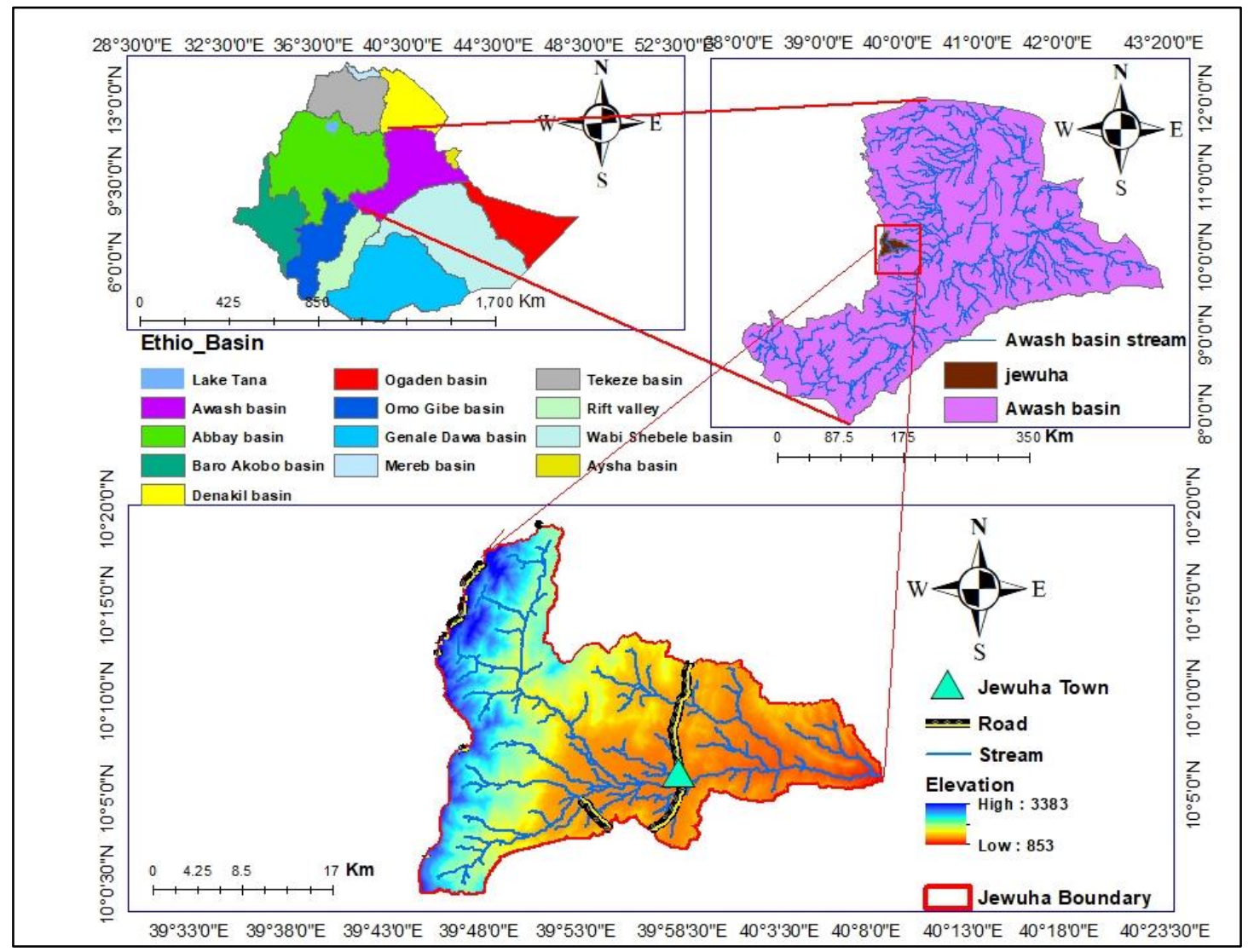

Fig.2.1 Location of the study area

55 The topography of the Jewuha watershed is characterized by diverse topographic conditions. The upper part of the watershed is characterized by mountainous and highly separated terrain with steep slopes and the downstream part is a gentle slope that is suitable for agricultural activity, with elevation ranges from $3555 \mathrm{~m}$ in the mountainous area to $1101 \mathrm{~m}$ in the lowland. The general topography of the catchments is undulating hills and flats.

59 The climate of the Jewuha watershed is characterized by high rainfall with low temperatures in the highland and 60 low rainfall with high temperatures in the low land area. According to the Ethiopian agro-climatic zone 61 classification, the climate of the study area ranges from hot temperate (Kola) around the low land of the Jewuha 62 town area to cool temperature (wurch) in the mountains and escarpment.

63 Rainfall distribution over the area is bimodal, characterized by a short rainy season (Belg) that occurs between 64 March and April and a long rainy season (kiremt) that occurs between June and August, with a dry season from 65 December to February. In the dry season, the rainfall ranges between 218 and 259mm, whereas in the wet season it 66 ranges between $600 \mathrm{~mm}$ to $1500 \mathrm{~mm}$.

67 The temperature in the study area is hot in the low land areas, reaching up to $34.4^{\circ} \mathrm{C}$ and the lowest temperature is recorded at Molale station on the highland, reaching up to $7^{\circ} \mathrm{C}$ and sometimes it is less than this value.

69 The land use land cover map gives the spatial distribution and classification of the various land use land cover 70 classes. Different land cover types have been found in the study area in terms of areal coverage. The important land 71 cover units are forest, shrubs, grassland, intensively cultivated, woodland, bare areas, and built-up areas. 
The types of soil found in the study area are Eutric Fluvisols, Vetric Cambisols, Leptosols, Eutric Cambisols,

73 Chromic Cambisols, Chromic Vertisols, Haplic Xerosols, Eutric Regosols and Cambic Arenosols.

\section{$74 \quad 2.2 \quad$ Data Types and Source}

75 To achieve the objectives of the study, different data inputs were collected from various sources and field 76 observations.

\section{$77 \quad$ 2.2.1 Metrological data}

78 Metrological data were collected from the National Metrological Agency of Ethiopia (NMAE). Shewa Robit and

79 Majeta climate stations were used for WGEN statistics calculation for SWAT using SWAT Weather database. The

80 SWAT Weather Database (Essenfelder 2018) is designed to be a friendly tool to store and process daily weather

81 data to be used with SWAT projects. It is capable of storing relevant daily weather information, easily generating.txt

82 files that are used for input during SWAT project and efficiently calculating the WGEN statistics from one or more

83 gauge stations. The daily weather data such as relative humidity (HMD), precipitation (PCP), solar radiation (SLR),

84 maximum and minimum temperature (TMP), wind speed (WND) and the batch file containing the location of the

85 gauge stations are loaded to SWAT Weather Database to calculate the WGEN statistics. The continuity and

86 consistency of the meteorological data were checked by the normal ratio method and double mass curve,

87 respectively.

\subsubsection{Hydrological data}

89 The daily stream flow data of (1985-2003) at Jewuha, 1988-2001 at Ataye, and 1995 - 2011 at Robi gauging station

90 were collected from the Ministry of Water, Irrigation and Energy (MoWIE). Ataye and Robi river were used for

91 validation of the regionalization technique in model parameter transfer for the ungauged sub wateshed.

\section{$92 \quad$ 2.2.3 Spatial data}

93 The data which is considered as spatial data includes DEM, land use land cover, soil map, and road map. Digital

94 elevation model (DEM) was obtained from the USGS website. The soil chemical parameters of $\mathrm{CaCO} 3$ and EC

95 covering the study area were obtained from the Harmonized World Soil Database (HWSD) on the FAO website, in

96 Environmental System Research Institute (ESRI) shape file format and Micro Soft Access database (Nachtergaele et

97 al. 2009) and soil physical properties were obtained from the map of the Awash river master plan soil survey study

98 from the GIS and remote sensing department in the Awash basin authority, Adama branch.

99 Land use land covers were obtained from the Water and Land Resource Center (WLRC), Addis Ababa; Ethiopia.

100 The road map is another spatial data set that is used to extract road proximity to assess the irrigation potential of the 101 study area and it is obtained from the DIVA-GIS website.

\section{$102 \quad 2.3 \quad$ Land suitability}

103 Land suitability assessment means evaluating the parcel of land for irrigation or agricultural development (FAO 104 1976). Soil physical and chemical properties and topography, a characteristic of the land includes soil depth, texture, 105 drainage, slope, $\mathrm{CaCO}$, EC and slope were taken to assess the suitability of the land in the study area. The digital 106 soil map was prepared and obtained from different organizations, then analyzed in a GIS environment. The soil 
characteristics that were considered for land suitability assessment were taken from different works of literature (M.Albaji et al. 2008; Sys et al. 1991; Worqlul et al. 2015; Kassaye et al. 2019; Mandal et al. 2018).

109 Among the different land suitability assessment techniques, this study was interested in parametric evaluation 110 systems prepared by (Sys et al. 1991) based on the soil characteristics. Parametric procedures usually allocate 111 numerical ratings to separate land characteristics or land qualities depending on their relevance to the land use 112 considerations. Then, they are combined into one numerical result using a mathematical equation as shown. These 113 soil characteristics are rated and used to calculate the capability index (CI). The rating table was obtained from the 114 tables prepared by (Sys et al. 1991).

$$
C I=A \times \frac{B}{100} \times \frac{C}{100} \times \frac{D}{100} \times \frac{E}{100} \times \frac{F}{100}
$$

Where $\mathrm{CI}$ is the Capability index for irrigation, $\mathrm{A}=$ soil texture rating, $\mathrm{B}=$ soil depth rating, $\mathrm{C}=\mathrm{CaCO} 3$ rating, $\mathrm{D}=$ $\mathrm{EC}$ rating, $\mathrm{E}=$ drainage rating, $\mathrm{F}=$ slope rating

118 Table 1 Capability indices (CI) class for land suitability

\begin{tabular}{|c|c|c|}
\hline \multicolumn{2}{|c|}{ Capability index } & Symbol \\
\hline$>80$ & Highly suitable & S1 \\
\hline $60-80$ & Moderately suitable & S2 \\
\hline $45-59$ & Marginally suitable & S3 \\
\hline $30-44$ & Currently not suitable & N1 \\
\hline$<29$ & Permanently not suitable & $\mathrm{N} 2$ \\
\hline
\end{tabular}

\subsection{SWAT Model Description}

120 The water availability in the study area was assessed using the SWAT hydrological model. SWAT (Arnold et al. 121 2002) can simulate hydrological cycles, vegetation growth, and nutrient cycling with a daily time step by 122 disaggregating a river basin into sub-basins and hydrologic response units (HRUs). SWAT uses the following water 123 balance equation to simulate the hydrologic cycle within a watershed.

$$
S W_{t}=S W_{o}+\sum_{i=1}^{n}\left(R \text { day }-Q_{\text {surf }}-E_{a}-W_{\text {seep }}-Q_{g w}\right)
$$

125 Where; $\mathrm{SW}_{\mathrm{t}}$ is the final water content $\left(\mathrm{mm} \mathrm{H}_{2} \mathrm{O}\right), \mathrm{SW}_{\mathrm{o}}$ is the initial soil water content on the day $\mathrm{i}(\mathrm{mm} \mathrm{H} 2 \mathrm{O}), \mathrm{t}$ is 126 time, days, Rday is the amount of precipitation on the day i ( $\mathrm{mm} \mathrm{H2O})$, Qsurf is the amount of surface runoff on the 127 day $\mathrm{i}(\mathrm{mm} \mathrm{H} 2 \mathrm{O})$, Ea is the actual evapotranspiration on the day $\mathrm{i}(\mathrm{mm} \mathrm{H} 2 \mathrm{O})$, Wseep is the amount of water entering 128 the vadose (unsaturated) zone from the soil profile on the day $\mathrm{i}\left(\mathrm{mm} \mathrm{H}_{2} \mathrm{O}\right), \mathrm{Qgw}_{\mathrm{gw}}$ is the amount of return flow on the 129 day $\mathrm{i}\left(\mathrm{mm} \mathrm{H}_{2} \mathrm{O}\right)$.

130 The model reflects the difference in evapotranspiration for various land use and soil type in the subdivision of 131 watersheds. The runoff was predicted separated from each HRU and routed to obtain the total yield for the 132 watershed. Hence, increase the accuracy and gives a better physical description of water balance. 
134 Sensitivity analysis is the way of determining the rate of change in model results concerning changes in model 135 parameters (Abbaspour 2012). Sensitivity analysis is important to provide information on the most important 136 parameters that affect the process in the study area and helps to decrease the number of parameters in the calibration 137 procedure by eliminating the parameters identified as not sensitive (Abbaspour et al. 2017). The sensitivity of the 138 parameter was selected based on the P-test and t-test values. The value that has a high $\mathrm{P}$ and a low $\mathrm{t}$ value is the most 139 sensitive parameter. The SUFI-2 (Sequential Uncertainty Fitting 2) program which is linked to SWAT-CUP 140 (Abbaspour 2012) was used for a combined model sensitivity and uncertainty analysis, calibration, and validation

141 procedures. From the two sensitivity analysis techniques in SWAT-CUP; global sensitivity analysis technique was 142 used.

\section{$143 \quad 2.4 .2 \quad$ Model Calibration and Validation}

144 Calibration is an effort to better parameterize a model to a given set of local conditions, thereby reducing the prediction uncertainty (Abbaspour et al. 2017). The prediction of uncertainty of SWAT model calibration and validation results was analyzed by the SWAT calibration uncertainties program known as SWAT-CUP (Abbaspour 147 2012). It is a public domain program that links Sequential Uncertainty Fitting (SUFI-2) (Abbaspour et al. 2007),

148 Particle Swarm Optimization (PSO) and Parameter Solution (ParaSol) (Beven and Binley 1992) and Marko Chain

149 Monte Carlo (MCMC). For this study, SUFI-2 was used for calibration of the model. To show the intimate 150 relationship between the simulation result, expressed as 95PPU, and the observation expressed as a single signal 151 (with some error associated with it), two statistics values are used (Abbaspour et al. 2007). These are the p-factor 152 and r-factor, which give a good measure of the strength of calibration results. The P-factor is the percentage of 153 measured data bracketed by the 95PPU band and the r-factor is a measure of the thickness of the 95PPU. The value 154 of the p-factor and R-factor is between 0 and 1 , and 0 to infinity, respectively. A p-factor of 1 and R-factor of 0 155 indicate simulations are exactly corresponding to the observed data (Abbaspour 2012).

$$
r_{\text {factor }}=\frac{\frac{1}{n} \sum_{t=1}^{n}\left(Q_{t}^{s, 97.5 \%}-Q_{t}^{s, 2.5 \%)}\right.}{\sigma_{o b s}}
$$

157 Where $Q_{t i}^{s, 97.5 \%}$ and $Q_{t i}^{s, 2.5 \%}$ are the upper and lower boundary of the 95PPU at time t and simulation i, 158 respectively, $n j$ is the number of data points and $\sigma_{o b s j}$ is the standard deviation of the $j t h$ observed variable

159 Model validation is the process of describing that a given site-specific model is capable of making satisfactory 160 simulations. It is the comparison of model results with an independent data set without further adjustment of the 161 model parameters. Validation embraces running a model using parameters that were estimated during the calibration 162 process and comparing the predictions to observed data not used in the calibration process. The hydrological data of 163 Jewuha River from 1990 - 1997 and 1998 - 2003 was used for the calibration and validation of the SWAT model, 164 respectively. 
166 Herein, the performance of the model was checked by statistical tests that can be used to judge the SWAT model.

167 For this study, Nash Sutcliffe efficiency (NSE), percent bias (PBIAS), and coefficient of determination $\left(\mathrm{R}^{2}\right)$ were 168 used as recommended by (Moriasi et al. 2007). The coefficient of determination $\left(\mathrm{R}^{2}\right)$ describes the proportion of the 169 variance in the measured data explained by the model. $\mathrm{R}^{2}$ ranges from 0 to 1 , with higher values indicating less error 170 variance, and typically, values greater than 0.5 are considered acceptable (Moriasi et al. 2007).

171 Percent bias (PBIAS) measures the average tendency of the simulated data to be higher or smaller than its observed 172 values. The optimal value of PBIAS is 0.0 , with lower magnitude values indicating an exact model simulation. The 173 negative value of PBIAS indicates the models overestimate the simulated and the positive shows the model 174 underestimates the simulated flow (Moriasi et al. 2007).

175

$$
N S E=1-\left[\frac{\sum_{i=1}^{N}\left(O_{i}-P_{i}\right)^{2}}{\sum_{i=1}^{N}\left(O_{i}-\bar{O}_{i}\right)^{2}}\right]
$$

$$
\text { PBIAS }=\left[\frac{\sum_{i=1}^{N}\left(o_{i}-P_{i}\right) \times 100}{\sum_{i=1}^{N} O_{i}}\right]
$$

$$
\mathrm{R}^{2}=\left[\frac{\sum_{\mathrm{i}=1}^{\mathrm{N}}\left(\mathrm{O}_{\mathrm{i}}-\overline{\mathrm{O}}\right)\left(\mathrm{P}_{\mathrm{i}}-\overline{\mathrm{P}}\right)}{\sqrt{\sum_{\mathrm{i}=1}^{\mathrm{N}}\left(\mathrm{O}_{\mathrm{i}}-\overline{\mathrm{O}}^{2}\right)} \sqrt{\sum_{\mathrm{i}=1}^{\mathrm{N}}\left(\mathrm{P}_{\mathrm{i}}-\overline{\mathrm{P}}\right)^{2}}}\right]^{2}
$$

178 Where $\mathrm{P}_{\mathrm{i}}=$ simulated flow, $\mathrm{O}_{\mathrm{i}}=$ observed flow, $\bar{O}_{i}=$ the mean of observed data, $\overline{\mathrm{P}}$ is predicted flow and the 179 remaining variable is stated above and $\mathrm{N}$ is the total number of observations.

180 The Nash-Sutcliffe efficiency(NSE) (Sutcliffe 2001) indicating how well the model expresses the variance in the 181 observation. It generally ranges from - $\infty$ to 1 the optimum value is unity and it shows a good explanation of the 182 observed versus simulated data fits on a one to one line.

183 Table 2 General performance rating; Source:(Moriasi et al. 2007; Arnold et al. 2012)

\begin{tabular}{cccc}
\hline Performance rating & NS & PBIAS & $\mathrm{R}^{2}$ \\
\hline Very good & $0.75<$ NS $<1$ & PBIAS $< \pm 10 \%$ & $0.75<\mathrm{R}^{2}<1$ \\
Good & $0.65<$ NS $<0.75$ & $\pm 10 \%<$ PBIAS $< \pm 15 \%$ & $0.65<\mathrm{R}^{2}<0.75$
\end{tabular}



Satisfactory
$0.5<\mathrm{NS}<0.65$
$\pm 15 \%<$ PBIAS $< \pm 25 \%$
$0.5<\mathrm{R}^{2}<0.65$
Unsatisfactory
NS $<0.5$
PBIAS > $\pm 25 \%$
$\mathrm{R}^{2}<0.5$

\subsubsection{Regionalization technique for ungauged sub watershed}

185 Regionalization is the process of transferring hydrological information (parameters) of a model from a gauged watershed to an ungauged watershed.

187 Among the different regionalization techniques, spatial proximity and physical similarity methods are widely used

188 (Oudin et al. 2008; Parajka et al. 2005). In this study, spatial proximity with Inverse Distance Weighting (IDW) was used to transfer the calibrated model parameter of the gauged watershed to the ungauged watershed. And IDW was used to estimate the weight of the ungauged watershed. The distance between the two watersheds was determined using GIS. This regionalization techniques were verified using leave-one-out cross validation, in which a single

192 gauged site is considered as ungauged and the transferred parameters to that site are entered into the SWAT-CUP to validate with the observed flow. Observed flow at Jewuha and the two neighbouring watersheds of Shewa Robit and Ataye gauged watersheds was used to estimate the flow in the ungauged sub-watershed of the Jewuha River. The calibrated parameters of the Jewuha and Robi watersheds were transferred to the other ungauged sub watersheds. The parameters transferred by this technique are added into the SWAT model using a manual calibration helper and then the SWAT model is run to obtain the flow for each sub watershed. The general formula for spatial proximity with the IDW method to regionalize the calibrated parameter of the gauged watershed is as follows.

$$
Z_{u g}=\sum_{i=1}^{n} w_{i} z_{i}
$$

Where $Z_{u g}$ is the estimated model parameter at the ungauged watershed; $\mathrm{n}$ is the total number of observed points

201 (gauges); $z_{i}$ is the calibrated parameter value at gauged watershed and $w_{i}$ is the weight contributing to the 202 interpolation

$$
w_{i}=\frac{\frac{1}{d_{i}^{2}}}{\sum_{i=1}^{n} \frac{1}{d_{i}^{2}}}
$$

204 Where $d_{i}$ is the distance between at the centroids of gauged and ungauged watershed

\subsection{Estimation of Irrigation Water Demand}

206 Irrigation water demand is estimated from the water requirement of the crop. The major crops adopted in the study 207 area include maize, cabbage and onion. Several methods and procedures are available to compute the crop water 208 requirement. The computer program available in FAO Irrigation and Drainage Paper No. 56 "CROPWAT", has 209 been used for the calculation of crop water requirements. 
211 Where $\mathrm{Kc}$ is crop coefficients and ETc is crop evapotranspiration in $\mathrm{mm}$

212 Irrigation water demand is derived from crop evapotranspiration (ETc) and effective rain fall which is calculated

213 based on USDA soil conservation service. Then the net irrigation water demand of the crop was calculated as 214 follows.

$$
N I W D=E T C^{-P e f f}
$$

216 The gross irrigation water demand of the crop has been calculated by considering the loss of water during 217 application of water to the irrigation field, loss in the canal through seepage and evaporation. Thus, so as to 218 compensate for this loss, irrigation efficiency was introduced. The irrigation project efficiency is between 0.45 and 2190.7 for surface irrigation and 0.7 to 0.9 for pressurized irrigation systems (Luo et al. 2011). Thus, for this study, 220 average irrigation efficiency was taken as $0.5,0.75$ and 0.85 for surface, sprinkler and pressurized irrigation systems, respectively.

$$
G I W D=\frac{N I W D}{\eta}
$$

\subsection{Irrigation Suitability Area Assessment}

224 The irrigation suitability of the study was assessed by weighing the factors of land suitability, land use land cover, 225 distance from the source, and distance from the road (Nigussie et al. 2019; Rediet et al. 2020; Kasye Shitu 2020).

\section{$226 \quad$ 2.6.1 Land use land cover suitability assessment}

227 The LULC of the study were reclassified based on the classification system of (FAO, 1976) using the 228 reclassification tool, which is an attribute generalization technique in ArcGIS, as highly suitable (S1), moderately 229 suitable (S2), slightly suitable (S3) and not suitable (N).

230 Table 3 Land use land cover suitability rating; Source:(Rediet et al. 2020; Gurara 2020)

\begin{tabular}{llll}
\hline LULC type & Definition & LULC rating (r) & Class \\
\hline Cultivated land & Highly suitable & 4 & $\mathrm{~S} 1$ \\
Grassland/bare land & Moderately suitable & 3 & $\mathrm{~S} 2$ \\
Shrub/bush/wood land & Slightly suitable & 2 & $\mathrm{~S} 3$ \\
Settlement/forest/wetland & Not suitable & 1 & $\mathrm{~N}$ \\
\hline
\end{tabular}

\subsubsection{Distance from the water source (river) suitability assessment}

232 The identification of irrigable land that is close to the water supply (rivers) was done by calculating the straight-line 233 (Euclidean) distance from the streams that is generated from a 20m x 20m cell size DEM in a GIS tool and then 234 reclassifying. The land which is nearest to the stream was considered the most suitable land for irrigation 235 development and the land which is far from the stream is slightly suitable (Birhanu et al. 2019; Worqlul et al. 2015). 
The land from the river was reclassified as highly suitable (S1), moderately suitable (S2), slightly suitable (S3) and

237 not suitable $(\mathrm{N})$.

238 Table 4 Distance from source suitability rating; Source:(Birhanu et al. 2019; Kassaye et al. 2019)

\begin{tabular}{clcc}
\hline Class & Definition & Rating $(\mathrm{r})$ & Distance from river $(\mathrm{Km})$ \\
\hline S1 & Highly suitable & 4 & $0-2$ \\
S2 & Moderately suitable & 3 & $2-4$ \\
S3 & Slightly suitable & 2 & $4-5$ \\
N & Not suitable & 1 & $>5$
\end{tabular}

\subsubsection{Distance from road suitability assessment}

240 The road maps obtained from the DIVA-GIS website were reclassified based on the classification system of (FAO 241 1976) using the reclassification tool in the GIS. It is classified as highly suitable (S1), moderately suitable (S2), 242 slightly suitable (S3) and not suitable (N) by ratings of 4, 3, 2, and 1, respectively.

243 Table 5 Distance from road suitability rating; Source: (Worqlul et al. 2015)

\begin{tabular}{clcc}
\hline Class & Definition & Rating (r) & Distance from road (Km) \\
\hline S1 & Highly suitable & 4 & $0-3$ \\
S2 & Moderately suitable & 3 & $3-5$ \\
S3 & Slightly suitable & 2 & $5-8$ \\
N & Not suitable & 1 & $>8$ \\
\hline
\end{tabular}

\subsubsection{Weighted overlay of irrigation suitability factors}

245 To find an overall suitable site for irrigation, a suitability model was created using the model builder in the GIS Arc

246 tools box to overlay the factor to map the suitable land. The weights developed above for each factor were overlaid

247 in GIS to undertake multi-criteria evaluation (MCE) (Khongnawang and Williams 2015). In a multi-criteria

248 evaluation, an attempt is made to combine a set of criteria to achieve a single composite basis for a decision

249 according to a specific objective. The relative importance/weight of criteria and sub-criteria was estimated using

250 multi-criteria evaluation through AHP, applied by using pairwise comparison of each suitability factor developed by

251 (Saaty 1977).

252 In pairwise comparison, each factor was matched head-to-head (one to one) with the other and a pairwise or 253 comparison matrix was prepared to express the relative importance. The diagonal elements of the pairwise 254 comparison matrix are assigned the value of unity since the diagonal of the matrix value was obtained by the 255 compared value of itself.

256 To fill the matrix, ratings were given for all factors on a 9 point continuous scale. For example, if one feels that land 257 suitability is very strongly more important than LULC suitability in determining whether it is suitable for irrigation, 258 one will enter 7 on this scale. However, if the reverse is true, one will give the value of $1 / 7$. The value is given based 259 on expert judgment and related literature reviews. 
Table 6 Pairwise comparison matric of factors

\begin{tabular}{lllll}
\hline Factor & Soil & LULC & Distance from river & Distance from road \\
\hline Soil & 1 & 2 & 3 & 4 \\
LULC & $1 / 2$ & 1 & 2 & 3 \\
Distance from river & 0.333 & 0.5 & 1 & 2 \\
Distance from road & 0.25 & 0.333 & 0.5 & 1 \\
Sum & 2.08 & 3.833 & 6.5 & 10 \\
\hline
\end{tabular}

261 Calculate the normalized decision matrix of the irrigation suitability factor, which is obtained by all the elements in 262 each column are divided by the sum of the columns as shown in the Table 9 below. The normalized value is 263 calculated from the pairwise comparison matrices (Aij).

$264 \quad N=\frac{\sum j}{c}$

265 Where $\mathrm{N}$ is normalized value, $\mathrm{j}$ is the column of the matrix and $\mathrm{c}$ is the values of the column of the factors

266 Table 7 Normalized value of factors

\begin{tabular}{lllll}
\hline Factor & Soil & LULC & Distance from river & Distance from road \\
\hline Land & 0.48 & 0.52 & 0.46 & 0.4 \\
LULC & 0.24 & 0.26 & 0.31 & 0.3 \\
Distance from river & 0.16 & 0.13 & 0.15 & 0.2 \\
Distance from road & 0.12 & 0.09 & 0.08 & 0.1 \\
\hline
\end{tabular}

267 The Eigenvectors and weights of the criteria were calculated from the normalized matrix through summation and 268 average of the row values of each element in the row, respectively.

269 Table 8 Eigenvector value of criteria

\begin{tabular}{ll}
\hline Factor & Eigenvectors \\
\hline Land & 1.86 \\
LULC & 1.11 \\
Distance from river & 0.64 \\
Distance from road & 0.39
\end{tabular}

$271 \quad W_{i}=\frac{\sum N}{x}$ 
272 Where $W_{i}$ the weights of the criteria, $\mathrm{N}$ is the row values of normalized matrix and $\mathrm{x}$ is the number of criteria for 273 suitability analysis.

274 With a weighted linear combination, factors are combined by applying weight or percent of influence to the 275 suitability of the irrigation obtained by the pairwise comparison technique. The multiplication was based on the 276 following equation.

$$
S_{i}=\sum_{i=1}^{n} W_{i} X_{i}
$$

278 Where $\mathrm{S}$ suitability, $\mathrm{W}_{\mathrm{i}}$ is the weight of factor, $\mathrm{X}_{\mathrm{i}}$ is criteria score of factor available water in the river in volume

279 The map obtained after overlaying was irrigation suitability, which are classified based on their degree of suitability 280 as highly suitable (S1), moderately suitable (S2), slightly suitable (S3) and not suitable (N) (FAO 1976).

281 Table 9 Irrigation suitability rating

\begin{tabular}{lll}
\hline Suitability rating range & Class & Definition \\
\hline 4 & S1 & Highly suitable \\
3 & S2 & Moderately suitable \\
2 & S3 & Slightly suitable \\
1 & N & Not suitable \\
\hline
\end{tabular}

\subsection{Irrigation Potential Area Assessment}

283 Irrigation potential (IP) is the land that is suitable for irrigation and that can be irrigated with the available surface 284 water at a selected diversion site.

285 Diversion sites are selected by considering different factors. Those includes, diversion site elevation must be larger 286 than the area being irrigated, it should be easily accessed by road, the site should be not be too far from the 287 command area of the project (Dai, 2016) and the river cross section should be straight and narrow.

288 After the estimation of suitable land, irrigation water demand and available surface water, the actual irrigation 289 potential of the study area was estimated. The actual irrigation potential at the selected diversion site was evaluated 290 using the following formula for each perennial and some intermittent rivers in the watershed.

$$
\mathrm{IP}(\mathrm{ha})=\frac{A W}{G I W D}
$$

292 Where GIWD $\left(\mathrm{m}^{3} / \mathrm{ha}\right)$ is gross irrigation water demand and AW $\left(\mathrm{m}^{3}\right)$ is available water in the river at selected 293 diversion site in $\mathrm{m}^{3} / \mathrm{ha}$ or $\mathrm{mm}\left(1 \mathrm{~mm}=10 \mathrm{~m}^{3} / \mathrm{ha}\right)$ 
294 The irrigation potential areas which are estimated for each diversion site might not be found along the river and its

295 delineation is difficult. In such case, manual delineation through trial and error was done by following the contour 296 line generated.

\section{RESULT AND DISCUSSION}

\section{$298 \quad 3.1 \quad$ Land Suitability for Irrigation Potential}

299 The result of land suitability analysis showed that about 12,373 ha of land are ranged in between moderately to 300 marginally suitable for surface irrigation, 31,138ha of land are ranged in between highly to marginally suitable for 301 sprinkler irrigation systems and 35,433ha of land are considered highly to marginally suitable for drip irrigation 302 systems.

\section{Suitable area (ha)}

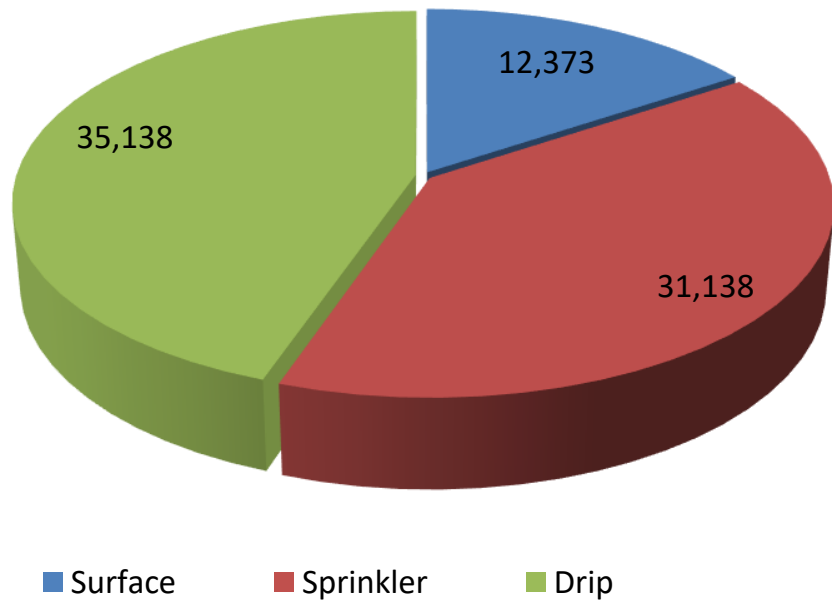

Fig.2 Land suitability chart

\subsection{Land use land cover suitability}

306 Based on the(FAO 1976) land suitability classification systems, the land use type was reclassified as 31,492ha 307 highly suitable (S1), 5756ha moderately suitable (S2), 30,599ha marginally/slightly suitable (S3), and 105ha not 308 suitable $(\mathrm{N})$. 


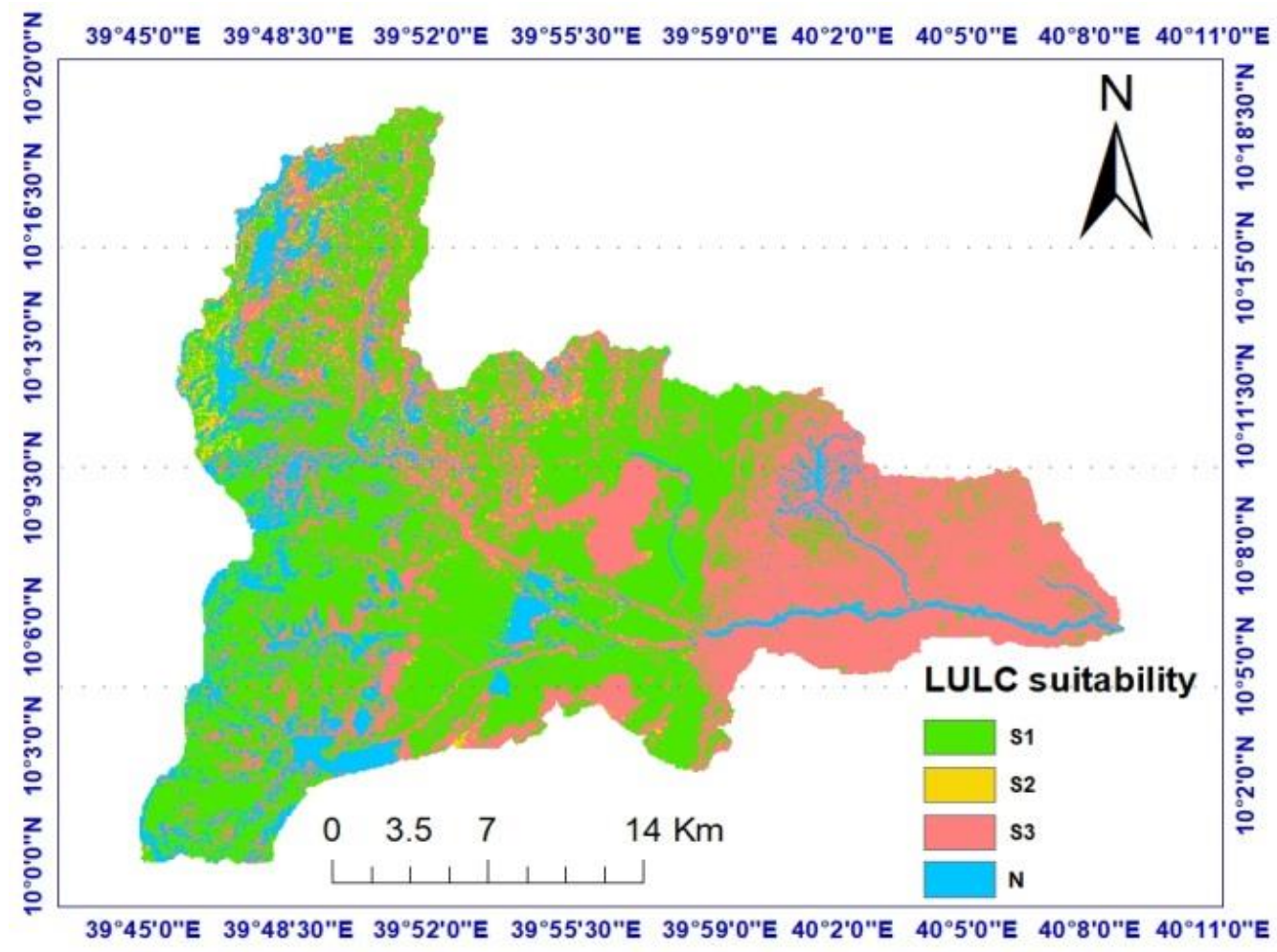

Fig.3 Land use land cover suitability

\section{$311 \quad 3.3 \quad$ Distance from River and Road Suitability}

312 The result of the analysis to estimate the suitability of the land from stream revealed that 27,991ha of land are highly

313 suitable, 18,780ha are moderately suitable 12,412ha of land are slightly suitable and 8779 ha are not suitable for 314 irrigation development.

315 The result of road suitability shows that 21,620 ha of land are highly suitable, 17,256ha are moderately suitable, 31618,257 ha are slightly suitable and 10,830ha are not suitable for irrigation.

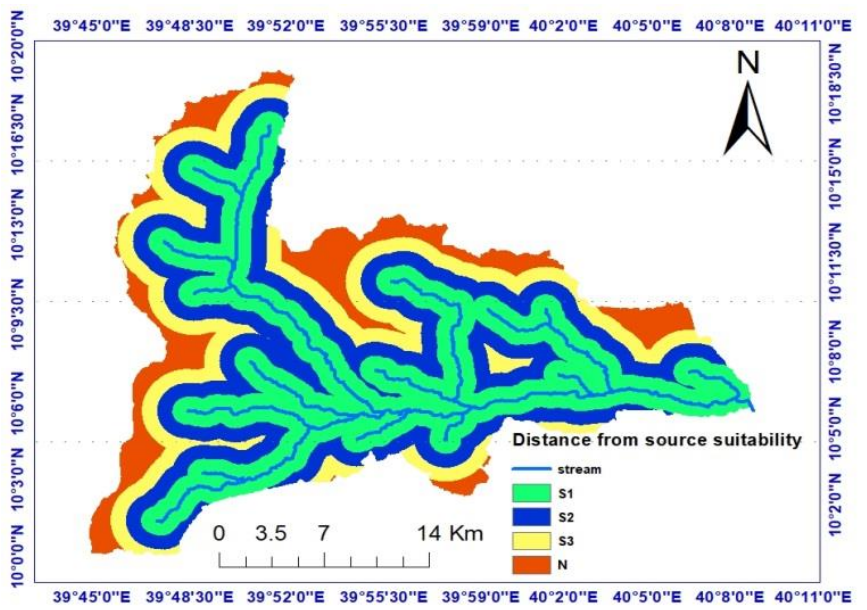

a. Distance from source (river)

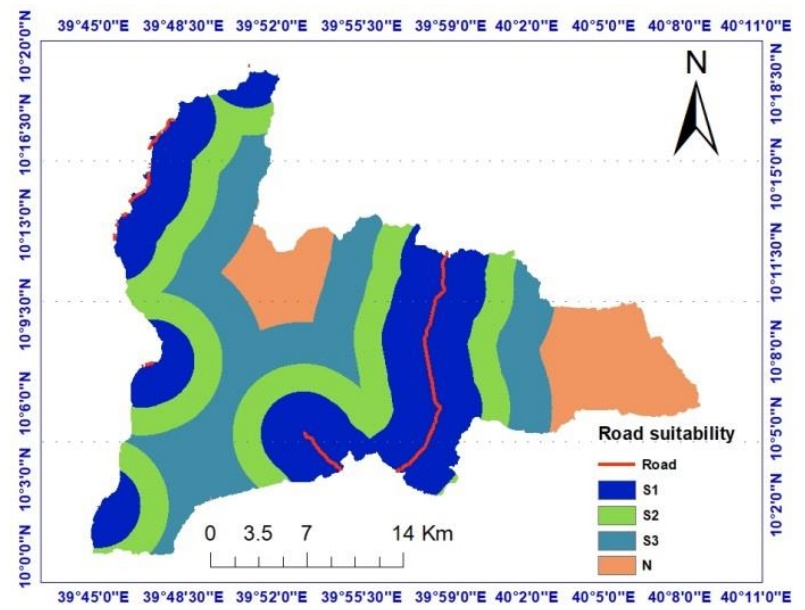

b. Distance from road

Fig.4 Distance from source (river) and road suitability 


\subsection{Surface water potential}

320 Surface water of the study area was assessed using SWAT hydrological model. The model in the study area can be 321 performed well with good performance.

\section{$322 \quad$ 3.4.1 SWAT model sensitivity Analysis}

323 Among twenty one model parameters that were selected for sensitivity analysis, sixteen parameters were found to be 324 sensitive under the category from high to low sensitive.

325 The most sensitive parameters of the study area in the SWAT model are R_CN2, ALPHA_BF, R_ESCO, R_EPCO, 326 V_GW_DELAY, V_ALPHA_BF, V_GWQMN, V_GW_REVAP, V_REVAPMN, V_RCHRG_DP, R_SOL_AWC, R_SOL_K, R_SLSUBBSN, R_SURLAG, R_HRU_SLP, V_SHALLIST.gw and R_OV_N. Among these sensitive model parameters, curve number (R_CN2), saturated hydraulic conductivity (R_SOL_K), Ground water delay (days) (V_GW_DELAY), Manning's "n" values for overland flow (R_OV_N) and available water capacity of the soil layer (R_SOL_AWC) are the top five sensitive parameters with a p-value less than 0.5 .

\subsubsection{Model calibration and validation}

332 Using the river discharge data obtained from the Minister of Water, Irrigation and Energy (MoWIE), the SWAT 333 model was calibrated at a monthly time scale.

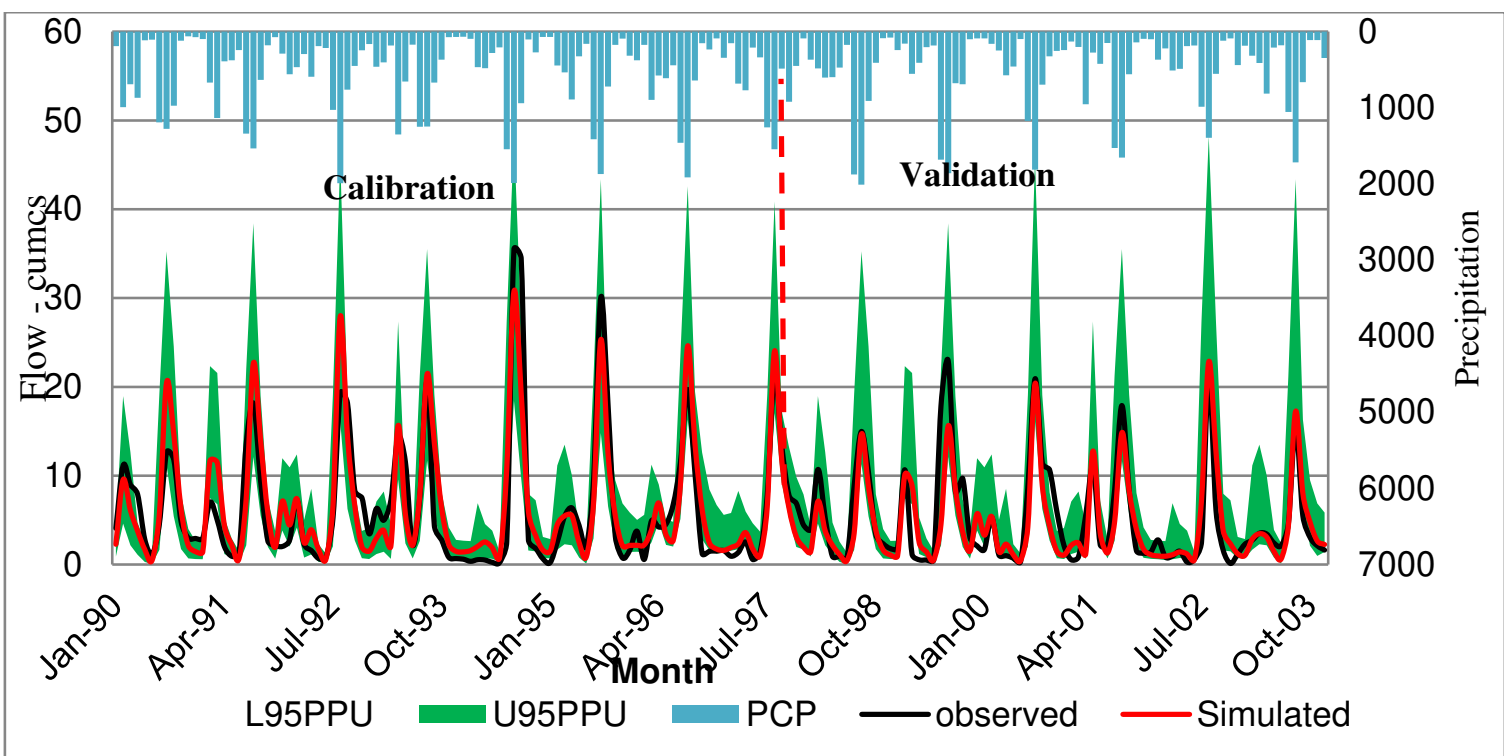

Fig.5 Jewuha river calibration and validation

\section{$336 \quad$ 3.4.3 Model performance evaluation}

337 The performance of the model was evaluated using time series plots of observed and simulated value and statistical measures such as coefficient of determination $\left(\mathrm{R}^{2}\right)$, Nash-Sutcliffe efficiency (NSE) and percent of bias (PBIAS).

339 The statistical analysis of the watershed showed very good agreement between observed and simulated monthly 340 flow. For the Jewuha watershed, the model overestimates the flow. The model was most affected by small 341 traditional diversion structures in the Jewuha watershed, which do not have sufficient data to enter the value into the 
SWAT model. This makes the model perform less. The p-factor is a good measure of the strength of calibration results. The P-factor is the percentage of measured data bracketed by the 95PPU band and its value is range between

3440 and 1 . When its value ranges between 0.7 and 1 the percentage of uncertainty is very good. As shown in Table 10, 345 the p-factor was 0.75 for the Jewuha River. This value shows that the 95PPU band is within acceptable ranges in the 346 watershed.

347 Table 10 Model performance

\begin{tabular}{lcc}
\hline Objective function & Calibration & Validation \\
\hline R $^{2}$ (Coefficient of determination) & 0.74 & 0.71 \\
NSE (Nash Sutcliff Efficiency) & 0.73 & 0.7 \\
PBIAS (Percent of bias) & -0.8 & 7.9 \\
RSR & 0.51 & 0.54 \\
p-factor & 0.75 & 0.74 \\
\hline
\end{tabular}

\subsubsection{Flow Regionalization}

350 The flow from the gauged watershed to the ungauged watershed was estimated through parameter regionalization 351 using the spatial proximity (SP) technique by Inverse Distance Weighting (IDW). For verification of the 352 regionalization technique in the watershed, the statistical parameters of the objective function are good and this 353 shows that applying the spatial proximity technique to transfer the model parameters to ungauged sub watershed to 354 estimate was acceptable. Thus, the flow in the ungauged sub watershed was estimated using the spatial proximity 355 (SP) regionalization technique.

356 Table 11 Mean monthly stream flow $\left(\mathrm{m}^{3} / \mathrm{s}\right)$ of ungauged sub watershed using spatial proximity regionalization

\begin{tabular}{lcccccccccccc}
\hline $\begin{array}{l}\text { Sub } \\
\text { watershed }\end{array}$ & Jan & Feb & Mar & Apr & May & Jun & Jul & Aug & Sep & Oct & Nov & Dec \\
\hline Gida & 0.5 & 0.97 & 0.87 & 0.83 & 0.8 & 0.4 & 1.06 & 2.62 & 1.83 & 1.13 & 0.8 & 0.7 \\
Lomi & 4.1 & 4.62 & 5.75 & 6.92 & 4.1 & 1.8 & 8.00 & 21.5 & 14.54 & 8.14 & 5.22 & 4.3 \\
Gundifit & 1.1 & 2.13 & 2.52 & 3.54 & 2.7 & 1.6 & 5.43 & 8.29 & 6.24 & 3.61 & 2.4 & 1.6 \\
Ashmaq & 0.1 & 0.42 & 0.50 & 0.74 & 0.5 & 0.3 & 1.24 & 1.77 & 1.09 & 0.46 & 0.3 & 0.2 \\
Samet & 0.4 & 0.78 & 0.90 & 1.30 & 0.9 & 0.6 & 2.35 & 2.99 & 1.77 & 0.90 & 0.7 & 0.5 \\
\hline
\end{tabular}

\section{$357 \quad 3.5 \quad$ Irrigation Water Demand}

358 CROPWAT model results include crop evapotranspiration (ETc) and effective rainfall to estimate the irrigation 359 water requirement of the crop. As shown in table 12, monthly gross irrigation water requirement of maize, cabbage 360 and onion was estimated throughout their full growth periods for both surface, sprinkler and drip irrigation systems. 
Table 12 Gross irrigation water demand ( $\mathrm{mm} / \mathrm{month})$

\begin{tabular}{lllllll}
\hline \multirow{2}{*}{ Irrigation Methods } & Crop type & Jan & Feb & Mar & Apr & May \\
& Onion & 135.15 & 59.3 & 89.85 & 37 & 0 \\
& Maize & 69.36 & 50.66 & 120.57 & 144 & 119.94 \\
Surface irrigation & Cabbage & 123.74 & 83.41 & 144.21 & 74.6 & 0 \\
& Average & 109.42 & 64.46 & 118.21 & 85.2 & 39.78 \\
\hline \multirow{3}{*}{ Sprinkler irrigation } & Mnion & 90.1 & 39.53 & 59.9 & 24.7 & 0 \\
& Maize & 46.24 & 33.77 & 80.38 & 96 & 79.96 \\
& Cabbage & 82.5 & 55.6 & 96.1 & 49.7 & 0 \\
& Average & 72.95 & 42.97 & 78.79 & 56.8 & 26.65 \\
\hline \multirow{3}{*}{ Drip irrigation } & Onion & 79.5 & 34.88 & 52.85 & 21.8 & 0 \\
& Maize & 40.8 & 29.8 & 70.92 & 84.71 & 70.55 \\
& Cabbage & 72.8 & 49.1 & 84.8 & 43.9 & 0 \\
& Average & 64.37 & 37.93 & 69.52 & 50.14 & 23.52 \\
\hline
\end{tabular}

\section{$363 \quad 3.6 \quad$ Irrigation Suitability Potential}

364 To find the irrigation suitability potential of the study area; land suitability maps, land use land cover suitability 365 maps, distance from stream suitability maps and distance from road suitability maps were overlay in a GIS 366 environment using a weighted overlay analysis tool in the spatial analysis tool. To overlay these maps, the factors 367 are given a weight.

368 Table 13 Weight developed for factors

\begin{tabular}{ll}
\hline Factors & $\mathrm{Wj}$ (Weight (\%) \\
\hline Land suitability & 47 \\
Land use land cover suitability & 27 \\
Distance from source suitability & 16 \\
Distance from road suitability & 10 \\
Sum & 100 \\
\hline
\end{tabular}

369 The consistency ratio (CR) was 0.02 , which is acceptable for weighting the factors to evaluate the irrigation 370 suitability of the watershed.

\section{$371 \quad$ 3.6.1 Surface irrigation suitability}

372 Assessment of the study area for surface irrigaion suitability revealed that $1 \%$ (581ha) are highly suitable, $16 \%$ 373 (10778ha) suitable, 59\% (40013ha) moderately suitable and 24\% (16274ha) are not suitable to develop a surface 
irrigation system. Of the total land area of the study, 51372ha of land are suitable for surface irrigation. The analysis

375 indicates that in the irrigation suitability map,a high portion of the cultivated area is found in the middle low land

376 area and is deemed suitable for surface irrigation due to its high soil depth and flat slope of less than $8 \%$, which is 377 suitable for surface irrigation.

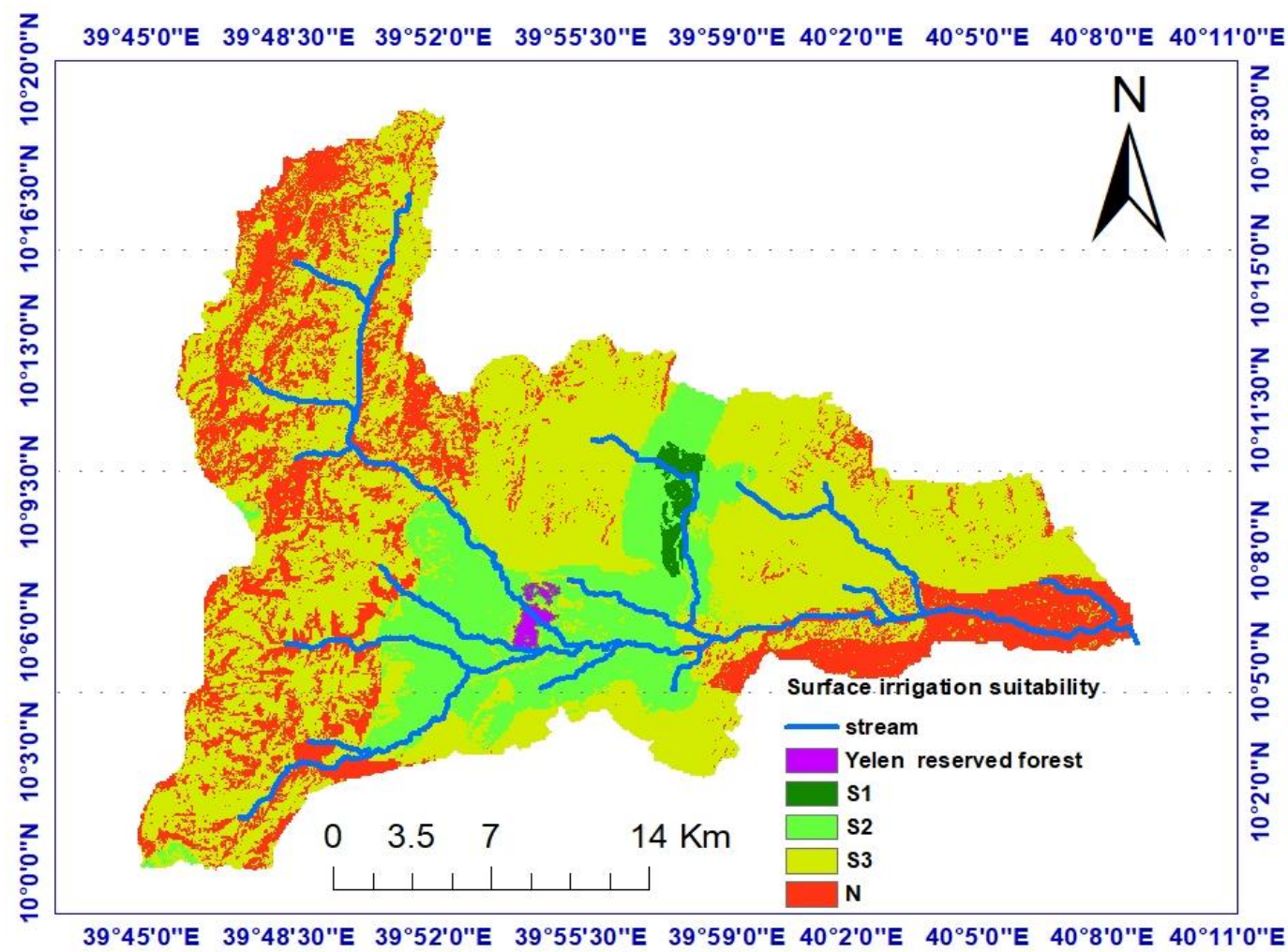

Fig.6 Surface irrigation suitability

\section{$380 \quad$ 3.6.2 Sprinkler irrigation suitability}

381 Assesment of the study area for sprinkler irrigtion suitability revealed that $4.5 \%$ (3029ha) are highly suitable, 26.5\% 382 (18042ha) are suitble, 46\% (31697ha) are moderately suitable and 23\% (15088ha) are not suitable to develop a 383 sprinkiler irrigation system. From the total land area of the study, 52768ha of land can be developed by the 384 sprinkiler irrigation system. 


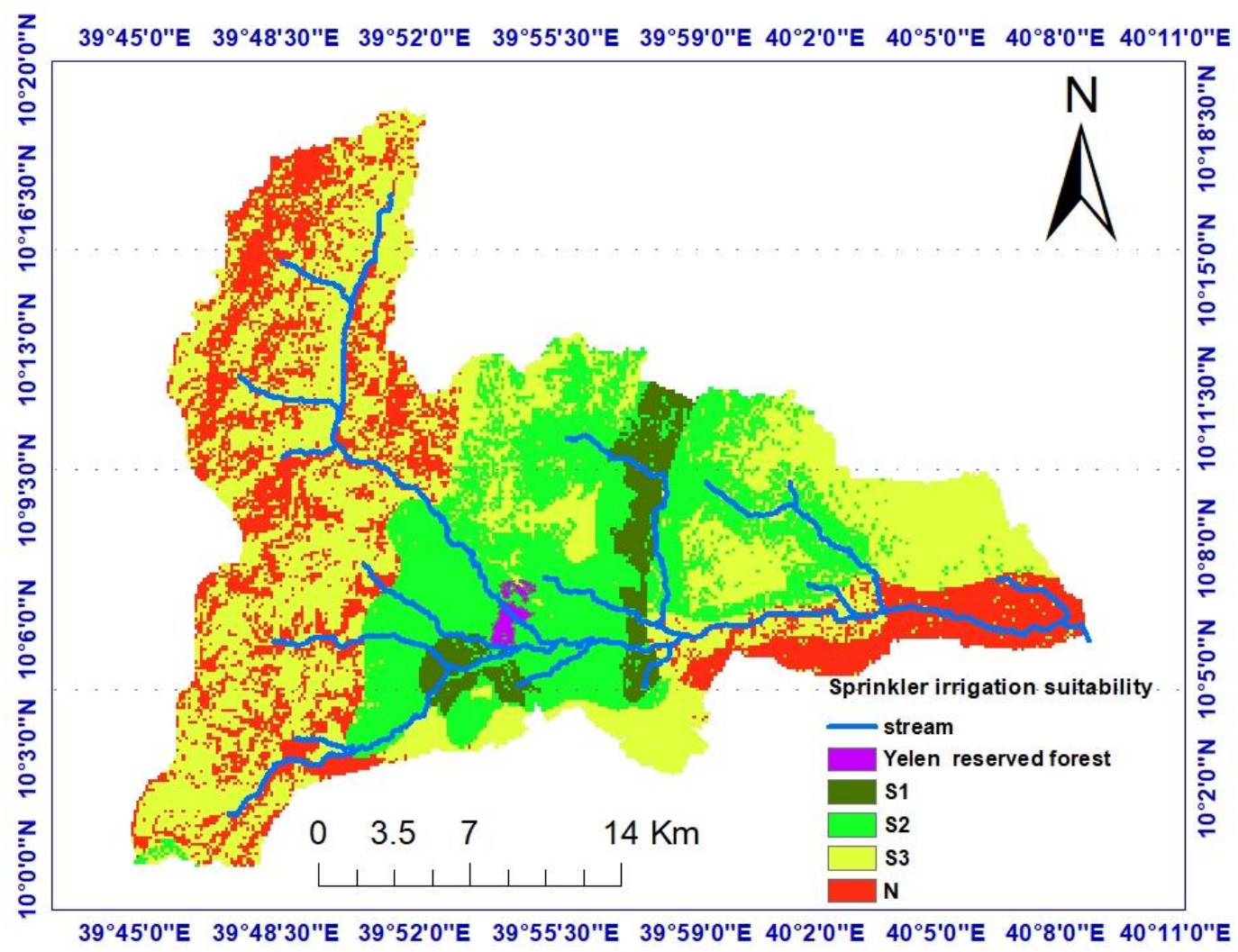

Fig.7 Sprinkler irrigation suitability

\section{$387 \quad$ 3.6.3 Drip irrigation Suitability}

388 The assessment of drip irrigation suitability in the study area revealed that 13\% (8498ha) are highly suitable, 25\% 389 (16971ha) are suitable, 40\% (27282ha) are moderately suitable, and 22\% (14855ha) are not suitable for drip

390 irrigation system. From the total land area of the study, 52751ha of land can be developed by the drip irrigation 391 system. 


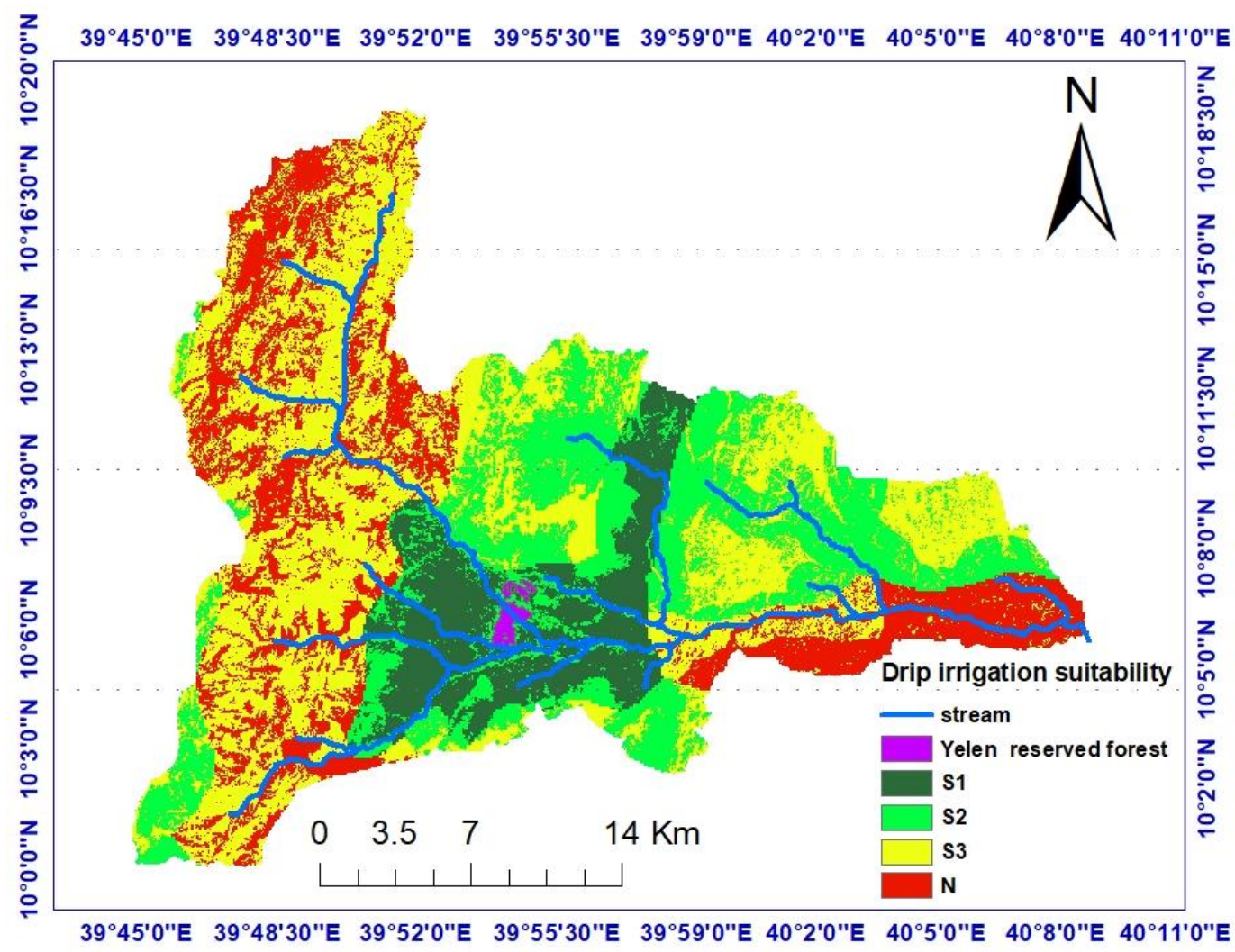

Fig.8 Drip irrigation suitability

\section{$394 \quad$ 3.6.4 Irrigation suitability of river catchments (sub watershed)}

395 The irrigation suitability of river catchments or sub watersheds as shown in table 14 below shows that 315 ha of the 396 area in Gida sub watersheds was categorized as highly suitable for surface irrigation, but the remaining sub 397 watersheds are not considered as highly suitable. For sprinkler irrigation suitability system 587ha, 603ha and 2 ha of 398 the area in Gida, Gundifit and Ashemaq are categorized under highly suitable for irrigation, respectively.

399 Table 14 Irrigation suitability of sub watershed

\begin{tabular}{|c|c|c|c|c|c|c|c|c|c|c|c|c|}
\hline \multirow{2}{*}{$\begin{array}{l}\text { Sub } \\
\text { watershed } \\
\text { Name }\end{array}$} & \multicolumn{4}{|c|}{ Surface irrigation (ha) } & \multicolumn{4}{|c|}{ Sprinkler irrigation (ha) } & \multicolumn{4}{|c|}{ Drip irrigation (ha) } \\
\hline & S1 & S2 & S3 & $\mathrm{N}$ & S1 & S2 & S3 & $\mathrm{N}$ & S1 & S2 & S3 & $\mathrm{N}$ \\
\hline Gida & 315 & 678 & 4409 & 266 & 587 & 3107 & 1950 & 25 & 588 & 3083 & 1961 & 34 \\
\hline Lomi & - & 302 & 10397 & 7036 & - & 785 & 10134 & 6836 & 163 & 729 & 9928 & 6909 \\
\hline Gundifit & - & 2283 & 2226 & 641 & 603 & 2213 & 1721 & 616 & 2071 & 823 & 1615 & 641 \\
\hline Ashemaq & - & 394 & 2253 & 1161 & 2 & 467 & 2203 & 1138 & 298 & 333 & 2165 & 1013 \\
\hline Samet & - & 163 & 3769 & 2225 & - & 230 & 3919 & 2025 & 32 & 1255 & 3018 & 1848 \\
\hline
\end{tabular}

400 For drip irrigation suitability systems, all the sub watershed are categorized as highly suitable, from the smallest 401 area, 32ha in the Samet river sub watershed to the largest 2014ha in Lomi river sub watershed. This shows that 402 pressurized irrigation systems are more suitable than surface irrigation systems in the Jewuha watershed. This was 
due to the fact that, pressurized irrigation method is more suitable for steep slopes than the surface irrigation

404 systems.

\section{$405 \quad 3.7 \quad$ Irrigation Potential Mapping}

406 From the analysis to estimate the irrigation potential from the available surface water and gross irrigation mater 407 demand, the irrigation potential of the watershed was estimated as shown in the table 15 and figure 9.

408 Table 15 Irrigation potential and surface water available at selected diversion site and their location

\begin{tabular}{|c|c|c|c|c|c|c|c|}
\hline \multirow[t]{2}{*}{$\begin{array}{c}\text { Diversion } \\
\text { site }\end{array}$} & \multirow[t]{2}{*}{$\begin{array}{c}\text { Water potential } \\
\qquad\left(\mathrm{Mm}^{3}\right)\end{array}$} & \multicolumn{3}{|c|}{$\begin{array}{l}\text { GIWR } \\
\left(\mathrm{m}^{3} / \mathrm{ha}\right)\end{array}$} & \multicolumn{3}{|c|}{$\begin{array}{c}\text { Irrigation } \\
\text { potential (ha) }\end{array}$} \\
\hline & & Surface & Sprinkler & Drip & Surface & Sprinkler & Drip \\
\hline Gida & 1.06 & 4173 & 2780 & 2460 & 254 & 381 & 431 \\
\hline Lomi & 8.4 & 4173 & 2780 & 2460 & 2014 & 3021 & 3415 \\
\hline Gundifit & 2.34 & 4173 & 2780 & 2460 & 560 & 842 & 951 \\
\hline Ashmaq & 0.34 & 4173 & 2780 & 2460 & 83 & 122 & 138 \\
\hline Samet & 0.78 & 4173 & 2780 & 2460 & 187 & 281 & 317 \\
\hline
\end{tabular}

Therefore, as shown in table 15 the actual irrigation potential of Jewuha watershed was found 3098ha for surface

410 irrigation, 4647ha for sprinkler irrigation and 5252ha for drip irrigation systems.

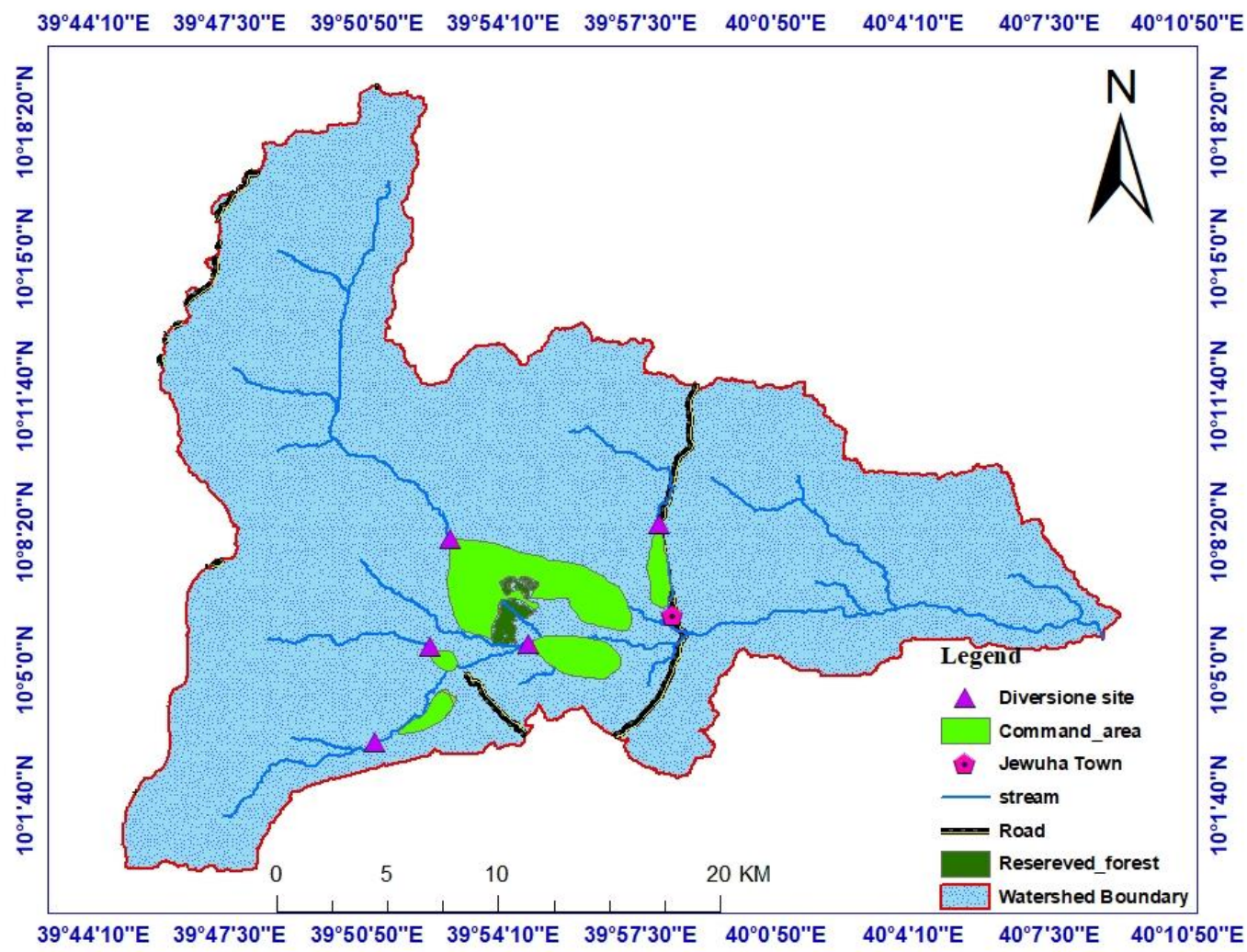

Fig.9 Irrigation potential maps and diversion site location 


\section{Conclusion}

414 In this study, the land suitability was analyzed using the parametric evaluation technique by considering topography 415 and soil physical and chemical characteristics. The result showed that 12,373ha of land are suitable for surface 416 irrigation, 31,138ha of land are suitable for sprinkler irrigation systems and 35,433ha of land are suitable for drip 417 irrigation systems. Suitability assessment of LULC, distance from source and distance from road shows that 67, 418 847ha, 59,183ha and 57,133ha are suitable for irrigation, respectively. From the weighted overlay of suitable land, 419 land use land cover, distance from water resource and distance from road reveals that $1 \%$ (581ha) are highly suitable, $16 \%$ (10,778ha) are moderately suitable, 59\% (40,013ha) are slightly suitable and 24\% (16,274ha) are not suitable to surface irrigation system. And 4.5\% (3,029ha) are highly suitable, 26.5\% (18,042ha) moderately suitble, $46 \%$ (31,697ha) slightly suitable and 23\% (15,088ha) are not suitable for sprinkiler irrigation system. For drip irrigation system $13 \%$ (84,98ha) are highly suitable, $25 \%$ (16,971 ha) moderately suitble, $40 \%$ (27,282ha) slightly suitable and $22 \%(14,855 \mathrm{ha})$ are not suitable.

To estimate surface water potential, the SWAT model was employed. The model was calibrated and validated by the observed flow. During the calibration and validation, the model performed good to simulate the hydrology of the watershed with a coefficient of determination $\left(\mathrm{R}^{2}\right)$, Nash-Sutcliffe efficiency (NSE) and Percent of bias (PBIAS) $0.74,0.73$ and 0.8 for calibration and $0.71,0.7$ and 7.9 for validation in Jewuha watershed. Spatial proximity regionalization technique was used to estimate the water potential for each ungauged sub watershed. The surface water potential of Gida, Jewuha, Gundifit, Ashmaq and Samet sub watershed was $1.06 \mathrm{Mm}^{3}, 8.4 \mathrm{Mm}^{3}, 2.34 \mathrm{Mm}^{3}$, $0.34 \mathrm{Mm}^{3}$ and $0.78 \mathrm{Mm}^{3}$ respectively.

The gross irrigation water demand was estimated using three major crops grown in the area, viz.maize, cabbage and onion. The average monthly demands were found to be $417 \mathrm{~mm}, 278 \mathrm{~mm}$ and $245 \mathrm{~mm}$ for surface, sprinkler and drip irrigation systems, respectively. Possible diversion site were selected based on the available command area to be irrigated below the proposed diversion site, accessible to road, $80 \%$ available flow and narrow river width. As a result, five (5) diversion sites were selected. The irrigation potential of the study area was estimated and mapped based on the available water and gross irrigation water demand to the selected diversion site. This result reveals that 3098ha, 4647ha and 5252ha of land are potential for surface, sprinkler and drip irrigation systems, respectively.

Funding information: This work was not supported financially from any institute or organization

440 Declaration of conflict of interest: Authors have declared that no conflict of interest.

\section{REFERENCE}

442 Abbaspour, Karim C., Jing Yang, Ivan Maximov, Rosi Siber, Konrad Bogner, Johanna Mieleitner, Juerg Zobrist,

Abbaspour, Karim C. 2012. “SWAT-CUP:SWAT Calibration and Uncertainty Programs,User Manual.” New York. and Uncertainty Analysis for Soil and Water Assessment: A Review of Papers from the 2016 International 
450 Arnold, J. G., D. N. Moriasi, P. W. Gassman, K. C. Abbaspour, M. J. White, R. Srinivasan, and C. Santhi. 2012. "SWAT: Model Use, Calibration, and Validation." American Society of Agricultural and Biological Engineers 55 (4): 1491-1508.

Arnold, J.G.; S.L.; Neitsch, J.R. Kiniry, R. Srinivasan, and J.R. Williams. 2002. "Soil and Water Assessment Tool—User's Manual 2002.” Temple,Texas.http://swat.tamu.edu/media/1294/swatuserman.pdf.

Arnold, Kiniry, Srinivasan, Williams, Haney, and Neitsch. 2012. "Soil \& Water Assessment Tool.”

AU. 2020. "Framework for Irrigation Development and Agricultural Water Management in Africa." Africa Union.

Awash Basin Authority. 2017. “Awash Basin Water Allocation Strategic Plan.” Addis Ababa.

Awlachew, Seleshi Bekele, Teklu Erkossa, and Namara Regassa. 2010. "Irrigation Potential in Ethiopia Constraints and Opportunities for Enhancing the System; International Water Management Institute.” Vol. 1.

Awulachew, Seleshi Bekele, Yilma, Aster Denekew, Loulseged, Makonnen, Willibald Loiskandl, Mekonnen Ayana, and Tena Alamirew. 2007. "Water Resource and Irrigation Development in Ethiopia." Colombo, Sri Lanka.

Awulachew, Seleshi Bekele and Douglas Merrey J. 2005. "Assessment of Small Scale Irrigation and Water Harvesting in Ethiopian Agricultural Development."

Beven, Keith, and Andrew Binley. 1992. "The Future of Distributed Models: Model Calibration and Uncertainty Prediction.” Hydrological Processes 6 (3): 279-98. https://doi.org/10.1002/hyp.3360060305.

Birhanu, Asfaw, Santosh Murlidhar Pingale, Bankaru Swamy Soundharajan, and Pratap Singh. 2019. "GIS-Based Surface Irrigation Potential Assessment for Ethiopian River Basin.” Irrigation and Drainage 68 (4): 607-16. https://doi.org/10.1002/ird.2346.

Dai, Xinyi. 2016. "Dam Site Selection Using an Integrated Method of AHP and GIS for Decision Making Support In.” Lund University. http://www.itc.nl/library/papers_2016/msc/gem/dai.pdf.

Essenfelder, Arthur Hrast. 2018. "SWAT Weather Database: A Quick Guide.," no. March.

FAO. 1976. "A Framework for Land Evaluation,FAO Soils Bulletin 32." Food and Agriculture Organisation of the United Nations,Rome,Italy.

FAO. 1992. "Crop Water Requirements, Irrigation and Drainage Paper 24." Food and Agriculture Organisation of the United Nations, Rome,Italy.

Gurara, Megersa Adugna. 2020. "Evaluation of Land Suitability for Irrigation Development and Sustainable Land

Haile, Gebremedhin Gebremeskel. 2015. "Irrigation in Ethiopia, a Review." Journal of Environment and Earth Science 3 (10): 264-69. 
Kassaye, Hussien, Woldu Gezahagn, and Birhanu Shimelis. 2019. "A GIS-Based Multi-Criteria Land Suitability Analysis for Surface Irrigation along the Erer Watershed, Eastern Harrarghe Zone, Ethiopia." East African Journal of Sciences 13: 169-84.

Kasye Shitu, Shemelis Berhanu. 2020. "Assessment of Potential Suitable Surface Irrigation Area in Borkena River Catchment, Awash Basin, Ethiopia.” Journal of Water Resources and Ocean Science 9 (5): 98-106. https://doi.org/10.11648/j.wros.20200905.12.

Khongnawang, T. and Williams, M. 2015. "Land Suitability Evaluation Using GIS-Based Multi-Criteria Decision Making." International Soil Conference, no. 2015: 246667.

Luo, Yunxiang, Baolin Su, Junying Yuan, Hui Li, and Qian Zhang. 2011. "GIS Techniques for Watershed

M.Albaji, S.Boroomand Nasab, H.A.Kashkuli, G.Sayyad, and S.Jafari. 2008. "Comparsion of Different Irrigation Methods Based on the Parametric Evaluation Approach in North Molasani Plain, Iran.” Journal of Agronomy 7(2):187-1.

Mandal, Biplab, Gour Dolui, Satpathy, and Sujan. 2018. "Land Suitability Assessment for Potential Surface Irrigation of River Catchment for Irrigation Development in Kansai Watershed, Purulia, West Bengal, India." Sustainable Water Resources Management 4 (4): 699-714. https://doi.org/10.1007/s40899-017-0155-y.

Melesse, Assefa M., Wossenu Abtew, and Shimelis G. Setegn. 2014. "Surface Water and Groundwater Resources of

Moriasi, D N, J G Arnold, M W Van Liew, R L Bingner, R D Harmel, and T L Veith. 2007. "Model Evaluation

Nachtergaele, Freddy, Harrij Van Velthuizen, Luc Verelst, Niels Batjes, Koos Dijkshoorn, Vincent Van Engelen, and Guenther Fischer. 2009. "Harmonized World Soil Database (Version 1.1)." FAO, Rome, Italy and IIASA, Laxenburg, Austria.

Nigussie, Getenet, Michael Mamaru A. Moges, Michael, and Tammo S. Steenhuis. 2019. "Assessment of Suitable

Parajka, J., R. Merz, and G. Blöschl. 2005. "A Comparison of Regionalisation Methods for Catchment Model Land for Surface Irrigation in Ungauged Catchments: Blue Nile Basin, Ethiopia.” Multidisciplinary Digital Publishing Institute 11: 1-17.

Oudin, Ludovic, Vazken Andre, Charles Perrin, and Claude Michel. 2008. "Spatial Proximity, Physical Similarity, Parameters." Hydrology and Earth System Sciences 9 (3): 157-71. https://doi.org/10.5194/hess-9-157-2005. 

Spatial Information Technology in Omo-Gibe River Basin.” Irrigation and Drainage Systems Engineering 9. https://doi.org/10.37421/idse.2020.9.245.

519 Saaty, Thomas L. 1977. "A Scaling Method for Priorities in Hierarchical Structures." Journal of Mathematical Psychology 15 (3): 234-81. https://doi.org/10.1016/0022-2496(77)90033-5.

521 Sutcliffe, J.E Nash and J V. 2001. "River Flow Forecasting through Conceptual Models PART I." Journal of Hydrology, North Holland Publishing Co, Amesterdam $34 \quad$ (2): 124-34. https://doi.org/10.1080/00750770109555783.

524 Sys, C., E. Van Ranst, and J. Debaveye. 1991. "Land Evaluation, Part I: Principles in Land Evaluation and Crop

525 Production Calculations." Agricultural Publications-NO 7,International Training Center for Post-Graduate $526 \quad$ Soil Scientists, University Ghent, 280.

527 Worku Ayalew, Dessalegn. 2018. "Theoretical and Empirical Review of Ethiopian Water Resource Potentials, 528 Challenges and Future Development Opportunities.” International Journal of Waste Resources 08 (04). 529 https://doi.org/10.4172/2252-5211.1000353.

530 Worqlul, Abeyou W, Amy S Collick, David G Rossiter, Simon Langan, and Tammo S Steenhuis. 2015. 531 "Assessment of Surface Water Irrigation Potential in the Ethiopian Highlands: The Lake Tana Basin." 532 ELSEVIER 129: 76-85. https://doi.org/10.1016/j.catena.2015.02.020. 